\title{
A Theory of Precautionary Regulatory Capital in Banking*
}

\author{
PhONG T. H. NGO \\ School of Finance and Applied Statistics, College of Business and Economics, \\ Australian National University, ACT, Australia
}

\begin{abstract}
The orthodox assumption in the banking literature is that capital requirements are a binding constraint on banking behavior. This is in conflict with the empirical observation that banks hold a buffer of capital well in excess of the minimum requirements. This paper develops a model where capital is endogenously determined within a profit-maximizing equilibrium. Optimality involves balancing the reduction in expected costs associated with regulatory breach with the excess cost of financing from increasing capital. We demonstrate that when the equilibrium probability of regulatory breach is less than one-half, banks are expected to hold precautionary capital.
\end{abstract}

\section{INTRODUCTION}

This paper presents a model of the financing decision for the banking firm. Virtually all models of bank decision making that are based on optimizing behavior have been concerned primarily with other questions and have not treated capital as a managerial or a bank decision variable. Rather, previous research (e.g., Kahane 1977; Koehn and Santomero 1980; Kim and Santomero 1988; Zarruk and Madura 1992) on the impact of capital regulation tended to assume that capital requirements are binding constraints on bank behavior.

This assumption seemed justified for the early work in capital requirements. Saunders and Wilson (1999) document bank capital ratios for Canadian, US and UK banks over a 100-year period between 1893 and 1992. There was a precipitous decline in capital ratios in the 35 years post-World War 2, that many attribute to a federal safety net - enjoyed by banks in most countries - that comprised of deposit insurance and a lender of last resort. The problem with the safety net was that it stifled the market incentives to maintain capital by insulating the counterparties in a banking contract from the full effects of a bank default. Moreover, this moral hazard problem was even greater for the

* Thanks are due to Shane Evans and Tom Smith for their comments on earlier versions of this paper. Thanks are also due to Simon Giles, Jeremy Hodgson, Stephen Mitchell and Peter Mudge for fruitful discussions during the preparation of the paper.

(C) 2007 The Author. Journal compilation (C) International Review of Finance Ltd. 2007. Published by Blackwell Publishing Ltd., 9600 Garsington Road, Oxford OX4 2DQ, UK and 350 Main Street, Malden, MA 02148, USA. 
largest banks that fell into the 'too-big-to-fail' category and therefore enjoyed regulatory protection from competition. ${ }^{1}$

In the United States, this led regulators to impose formal restrictions on leverage in 1983, which steadied the decline. Up until the inception of the Basel Capital Accord in 1988, capital ratios remained low and very close to the regulatory minimum requirement; this led many academics and industry analysts to conclude that the ever increasing competitive environment in which banks operated inevitably led banks to maintain the lowest permissible capital level. Although this 'corner solution' assumption, which has become a standard feature of most academic models of banking, may have suitably characterized the period from the end of World War 2 until Basel was introduced, it has become increasingly inappropriate over the last decade to 15 years.

If we extend the time frame beyond that studied by Saunders and Wilson (1999), even the most casual inspection of bank balance sheets will reveal stark inconsistencies with the view that regulators impose binding capital constraints on banks. The following tabulation reports the median capital ratios for banks in selected Organization for Economic Co-operation and Development (OECD) countries between 1990 and 1997. The data clearly show that banks hold capital well in excess of the minimum regulatory requirement of $8 \%$ outlined in the Basel Accord. Similar evidence is reported in Milne (2002) and Bernauer and Koubi (2002), who also show that capital ratios of Japanese banks are similar to those of the European banks, while Ngo (2006) calculates the mean capital ratio for a sample of 2500 US banks between March 1996 and March 2005 to be over $16 \%$, well above the minimum requirement.

What is more, Milne (2002) points out that viewing capital regulation as a system of ex-ante enforcement is problematic because regulators are resource constrained and not able to monitor the capital position of banks continuously. In the event that regulators actually observe breach of capital requirements, regulators do not acquire total control over the bank's operations. Instead, regulators have a limited range of interventionary measures that include involvement in the management process, public rebuke or, in an extreme case, issuing a cease-and-desist order.

As an aside, it should be noted that this is not the first paper that has allowed capital to be a decision variable. However, previous papers analyzing the capital decision for banks have ignored any potential influence of minimum capital requirements on a bank's optimal level of capital. Baltensperger (1980) presents a model where banks choose a level of capital that weighs up the benefits of reduced insolvency costs against the costs of holding more capital, which is assumed to be greater than the cost of debt - potential bankruptcy provides

1 The regulation of bank capital is therefore often justified to attain a balance between the conflicting objectives of preventing costly bank runs with the moral hazard induced by the safety net (see Furlong and Keeley 1989; Keeley 1990; Kaufman 1991; Berger, Herring and Szego 1995). 


\section{Capital Requirements in Banking}

banks with an incentive to hold a positive amount of capital. Pringle (1974) has also discussed the bank's capital decision but in a model that ignores bankruptcy costs, which is stressed in Baltensperger's (1980) analysis. The Pringle (1974) model treats the capital decision essentially as a liquidity management problem similar in vein to the reserve management models of Poole (1968) and Baltensperger (1974). Under the assumption of imperfect capital markets, where deposits follow a stochastic (although exogenous) distribution, he shows that banks can obtain additional funds in the form of capital at a given marginal cost and that optimal capital is attained when the excess marginal revenue on loans is equal to the excess marginal cost of capital.

The reasons outlined above suggest that orthodox analysis, although convenient, needs to be supplemented with alternative theories as to why and how banks choose their capital ratios. The current paper presents a model in which bank capital is determined endogenously in a profit-maximizing equilibrium where capital regulations act not as an ex-ante-binding constraint, but rather, act more like a system of ex-post sanctions for regulatory breach that provide banks with an ex-ante incentive to hold capital in excess of official requirements - what we call precautionary capital. Penalties for regulatory breach need not be monetary; however, for simplicity, we model the cost of regulatory breach in monetary terms and view this cost as encapsulating all relevant costs.

The present paper is most similar in flavor to that of Milne and Whalley (2001) in the sense that their paper also views capital regulation as an incentive mechanism rather than a binding constraint. They develop a continuous time model with endogenous capital to investigate bank risk-taking behavior under capital regulations with random regulatory audit. They show that banks with sufficient franchise value maintain a buffer of excess capital and that regulatory capital requirements have no long-run effect on bank risk taking. This paper, however, adopts a very different approach and seeks to answer a different set of questions. More precisely, we show that banks are expected to hold precautionary capital to avoid the expected costs associated with breaching regulatory guidelines and also demonstrate that this is expected to occur when the equilibrium probability of regulatory breach is less than one-half. The relevance of this finding to the policy debate is also explored.

We also note that, despite the aims of the Basel Accord to provide a 'level playing field' by harmonizing capital standards, there exist large differences in cross-national capital ratios observed in the last decade (see Table 1). The model suggests that a possible explanation for the observed differences in crossnational capital ratios is the varying levels of severity of ex-post sanction in the event of breach (or regulatory forbearance) at the national level. Consequently, the fact that US and UK banks hold more precautionary capital than their counterparts in Europe and Japan implies that US and UK regulators must be more severe with punishment in the event of regulatory breach. We look at 
Table 1 Median capital ratios 1990-1997

\begin{tabular}{lrrrrrrrrrrrr}
\hline & \multicolumn{2}{c}{ Germany } & \multicolumn{2}{c}{ France } & \multicolumn{2}{c}{ Italy } & \multicolumn{2}{c}{ NL } & \multicolumn{3}{c}{ UK } & \multicolumn{2}{c}{ US } \\
\hline 1990 & 9.1 & $(4)$ & 8.0 & $(8)$ & 9.6 & $(4)$ & - & - & 10.3 & $(8)$ & 8.4 & $(2)$ \\
1991 & 8.8 & $(7)$ & 8.7 & $(10)$ & 9.0 & $(7)$ & - & - & 12.0 & $(12)$ & 9.6 & $(88)$ \\
1992 & 9.3 & $(7)$ & 8.7 & $(11)$ & 9.2 & $(10)$ & 10.3 & $(3)$ & 12.0 & $(13)$ & 11.4 & $(224)$ \\
1993 & 9.1 & $(9)$ & 9.0 & $(13)$ & 9.7 & $(12)$ & 11.2 & $(5)$ & 13.1 & $(14)$ & 11.9 & $(328)$ \\
1994 & 9.6 & $(10)$ & 9.8 & $(13)$ & 10.5 & $(15)$ & 12.8 & $(8)$ & 14.4 & $(17)$ & 11.8 & $(409)$ \\
1995 & 9.4 & $(11)$ & 9.7 & $(16)$ & 11.0 & $(17)$ & 12.5 & $(8)$ & 15.0 & $(19)$ & 12.1 & $(445)$ \\
1996 & 9.4 & $(11)$ & 9.9 & $(16)$ & 10.2 & $(15)$ & 12.4 & $(8)$ & 15.4 & $(18)$ & 11.9 & $(445)$ \\
1997 & 9.9 & $(8)$ & 10.4 & $(13)$ & 10.2 & $(13)$ & 10.8 & $(6)$ & 14.2 & $(17)$ & 11.8 & $(440)$ \\
$1990-1997$ & 9.4 & $(67)$ & 9.2 & $(100)$ & 10.1 & $(93)$ & 11.3 & $(38)$ & 14.2 & $(118)$ & 11.8 & $(2381)$ \\
\hline
\end{tabular}

Note: The table reports the median capital ratios for banks in selected OECD countries between 1990 and 1997. The data clearly show that banks have capital ratios [(total capital/total assets) $\times 100$ ] well in excess of minimum regulatory requirement of $8 \%$ outlined in the Basel Accord. The notation used in the table is defined as follows: UK,United Kingdom; US, United States; NL, the Netherlands; OECD, Organization for Economic Co-operation and Development. The figures in the parentheses are the number of bank observations.

Source: de Bondt and Prast (1999).

anecdotal evidence from the United States, which is suggestive that one reason for believing that US regulatory authorities are relatively stringent is the result of political pressure from Congress to 'keep the banks in check' after the politically sensitive decision was made to provide a de facto bailout to US banks in the aftermath of the Latin American debt crises.

Notwithstanding this, some authors (Genschel and Plumper 1996; the Basel Committee 1999) attribute the holding of capital in excess of regulatory guidelines to 'market discipline' - for example, pressure from debt holders and ratings agencies. This hypothesis, however, does not adequately explain why smaller banks who do not borrow on interbank markets or issue securities also hold precautionary capital. Nor does it explain why there are large variations in cross-national capital ratios. The empirical literature trying to assess whether market incentives have been the reason for the buildup in capital is in its infancy and has found mixed results. Flannery and Rangan (2004) attribute the capital increase of the 1990s to enhanced market incentives to monitor and price large banks' default risks, while Bernauer and Koubi (2002) show that better capitalized banks experience lower borrowing costs, thus if competition is strong, this incentive may be the reason for the widespread over-compliance with existing regulations. They conclude, however, that competition is not sufficient to substitute for regulation because significant systematic effects - such as free riding and moral hazard - continue to exist.

This paper therefore provides an alternative explanation for the observation that banks typically hold capital in levels well above what is officially required. It is possible (most likely) that nonbinding capital constraints are a result of market discipline as well as banks trying to avoid the costs associated with 
breaching requirements; thus, the findings of this paper should be considered complementary to the market discipline hypothesis. ${ }^{2}$

The rest of this paper is organized as follows: the next section introduces a simple model of bank optimization similar to that of Baltensperger (1980). The model is then extended to incorporate capital requirements and implications for policy are explored. Section IV suggests that a possible explanation for the observed differences in cross-national capital ratios is the varying degrees of regulatory forbearance at the national level and provides evidence for why this may be the case. The final section concludes.

\section{THE MODEL}

Consider a single-period model of a banking firm. At the start of the period, the bank accepts $D$ dollars of deposits and offers a nominal return of $i$ to depositors. The bank also issues equity capital $K \in[0, L]$ at the beginning of the period at a cost of $\rho>i$ to finance an exogenous loan portfolio $L{ }^{3}$ Following Zarruk and Madura (1992), the bank faces uncertainty regarding the amount of loan losses $X \in[0, L]$. Let the probability density of $X$ be known to the banks and denote it as $f(X)$. The bank operates in a competitive environment and receives the market loan rate $r \geq \rho$ for its portfolio of assets. At the beginning of the period, the bank's balance sheet is given by

$$
L=D+K
$$

The goal of the bank is to select a capital structure so as to maximize its expected profits when faced with bankruptcy costs. A bank is defined to be bankrupt if, at the end of the period, its assets plus period income is less than its accumulated debt. That is, a bank is bankrupt if the following condition holds:

$$
(L-X)+r(L-X)-(1+i) D<0
$$

By substituting in the budget constraint and rearranging so that we have $X$ on the left-hand side, equation (2) can be rewritten in a more convenient fashion

$$
X>\left(\frac{1+i}{1+r}\right) K+\left(\frac{r-i}{1+r}\right) L \equiv \hat{X}
$$

Equation (3) tells us that a bank becomes insolvent if loan losses exceed some critical level $\hat{X}$. Given our assumptions, notice that $\hat{X}$ is increasing in $K, L$ and $r$ and decreasing in $i$ and $D$. Suppose that the cost of bankruptcy is positively related to the capital deficiency $(X-\hat{X})$, and for simplicity assume that the cost

2 It is also worth mentioning that prior empirical investigations into the effectiveness of regulation in influencing actual capital levels have not produced a definitive answer. For example, Peltzman (1970) and Dietrich and James (1983) found no regulatory effect on bank capital whereas Mingo (1975) and a recent study by de Bondt and Prast (1999) find that capital regulation seems to be effective in influencing bank capital ratios.

3 For now, we assume that there are no capital requirements and that $\rho$ and $i$ are constant. We relax these assumptions later in the paper. 
per dollar of deficiency is constant at $c$. The expected cost of bankruptcy can then be expressed as:

$$
B=c \int_{\hat{X}}^{L}(X-\hat{X}) f(X) d X
$$

where the probability of bankruptcy is given by $\int_{\hat{X}}^{L} f(X) d X$. Optimality involves choosing $K$ to maximize expected profit, which is defined as expected income from the loan portfolio, less interest, capital and expected bankruptcy costs, or:

$$
\Pi=r \int_{0}^{L}(L-X) f(X) d X-i D-\rho K-B
$$

The first-order condition yields the following result.

Proposition 1 (Demand for Equity Capital). The demand for equity capital $K^{*}$ must satisfy the following condition:

$$
-B_{K}=\rho-i
$$

where $B_{K}=\frac{\partial B}{\partial K}=-c \int_{\hat{X}}^{L}\left(\frac{1+i}{1+r}\right) f(X) d X$.

Proof. See Appendix A.

The bank's optimal decision involves balancing the expected costs of bankruptcy against the additional cost of issuing equity instead of deposits. Equation (6) tells us that at the optimum, the marginal cost of increasing equity by an infinitesimally small amount, $(\rho-i)$, is equal to the marginal benefit from the associated reduction in expected bankruptcy costs $-B_{K}$. The optimal demand for bank equity is therefore determined by the magnitudes of $\rho, i, r, c$ and the distribution of $X .{ }^{4}$ From equation (6), we also have the following result:

Corollary 1 (Equilibrium Probability of Bankruptcy). The equilibrium probability of failure is given by

$$
\operatorname{Pr}\left[X>\hat{X}^{*} \equiv\left(\frac{1+i}{1+r}\right) K^{*}+\left(\frac{r-i}{1+r}\right) L\right]=\frac{\rho-i}{c}\left(\frac{1+r}{1+i}\right)
$$

where $0<\frac{\rho-i}{c}\left(\frac{1+r}{1+i}\right)<1$. For a given distribution of $X$, the equilibrium probability of bankruptcy is increasing in $\rho$ and $r$ and decreasing in $i$ and $c$.

Proof. See Appendix A.

In other words, the bank should choose $K$ such that the probability of bankruptcy - given by the left-hand side of (7) - is equal to $\frac{\rho-i}{c}\left(\frac{1+r}{1+i}\right)$, which is less than unity and greater than zero. More generally, $K^{*}$ can be considered as the bank's demand for capital, and (7) makes this demand a function of the cost of equity capital, deposit rate, loan rate, cost per dollar of capital deficiency and

4 Of course, an interior optimum also requires $B_{K K}>0$; otherwise, corner solutions are obtained. 
the distribution of loan losses. Inspection of (7) reveals the following comparative static results with regard to the demand for equity capital:

Corollary 2 (Comparative Statics). The demand for equity capital $K^{*}$ is decreasing in $\rho$ and $r$ and increasing in $i$ and $c$. That is $\frac{\partial K^{*}}{\partial \rho}<0, \frac{\partial K^{*}}{\partial r}<0$, $\frac{\partial K^{*}}{\partial i}>0, \quad \frac{\partial K^{*}}{\partial c}>0$.

Proof. See Appendix A.

These results seem quite reasonable. An increase in the cost of capital, ceteris paribus, increases the marginal cost of capital and thus the bank chooses to hold less of it in equilibrium. On the other hand, increasing the deposit rate reduces the marginal cost of capital and also increases the probability of bankruptcy. As a consequence, banks will hold more capital in equilibrium. For a given distribution of loan losses, an increase in the loan rate increases the income earned on assets and thus banks are less likely to fail than what is optimal. That is, it will reduce the probability of failure below what is optimal - banks therefore adjust capital downwards. Finally, an increase in the cost per dollar of capital deficiency leads to an increase in expected bankruptcy costs; banks therefore increase capital such that there is a reduction in the equilibrium probability of failure.

\section{A. A model with capital requirements}

Up till now, we have ignored minimum capital requirements. They can easily be incorporated into this framework. Suppose the regulator requires that excess capital $(\hat{X}-X)$ at the end of the period be at least equal to some fixed proportion $q$ of end of period loans $(L-X)$. That is, $(\hat{X}-X) \geq q(L-X)$. Consequently, a deficiency in regulatory capital occurs if $(\hat{X}-X)<q(L-X)$, or more conveniently, if the following is true:

$$
X>\left(\frac{(1+i)}{(1+r)(1-q)}\right) K+\left(\frac{r-i-q(1+r)}{(1+r)(1-q)}\right) L \equiv X_{R}
$$

The preceding condition tells us that if loan losses exceed some critical level $X_{R}$ - which is now in part determined by regulatory requirements - then a bank is in breach of regulatory capital requirements. Once again, let the cost of regulatory breach be positively related to the deficiency in regulatory capital $\left(X-X_{R}\right)$, and also assume that the cost per dollar of deficiency is constant at $c_{R}$. The expected costs of regulatory breach can then be expressed as

$$
R=c_{R} \int_{X_{R}}^{L}\left(X-X_{R}\right) f(X) d X
$$

where the probability of regulatory breach is given by $\int_{X_{R}}^{L} f(X) d X$. In a manner similar to Milne (2002), we can think of these costs as an ex-post cost imposed by regulators on shareholders if capital requirements are found to be breached. However, and possibly of equal importance to the actual costs of regulatory 
breach are the costs caused by the bank's efforts to avoid regulatory breach. A bank will start to rearrange and reorganize its portfolio before breach actually occurs if its capital position falls below some 'minimum' level as a consequence of a 'poor' year, in order to prevent breaching regulatory requirements. Once again, optimality involves choosing $K$ so as to maximize expected profits, where the profit function is now given by

$$
\Pi=r \int_{0}^{L}(L-X) f(X) d X-i D-\rho K-R
$$

The first-order condition yields an almost identical result as Proposition 1:

Proposition 2 (Demand for Equity Capital under Regulatory Requirements). When regulatory requirements on capital exist, the demand for equity capital $K_{R}^{*}$ must satisfy

$$
-R_{K}=\rho-i
$$

where $R_{K}=\frac{\partial R}{\partial K}=-c_{R} \int_{X_{R}}^{L}\left(\frac{(1+i)}{(1+r)(1-q)}\right) f(X) d X$.

Proof. See Appendix A.

Once again, we have the bank balancing up the additional costs of issuing capital with the reduction in expected costs of regulatory breach. The marginal cost of increasing capital remains the difference between the cost of capital and the deposit rate $(\rho-i)$, while the marginal benefit is no longer the reduction in expected bankruptcy costs; rather, it is the reduction in expected costs of regulatory breach. Notice now that the demand for capital is also a function of $q$ as well as $\rho, i, r, c_{R}$, and the distribution of $X$. We also have the following result:

Corollary 3 (Equilibrium Probability of Regulatory Breach). The equilibrium probability of regulatory breach is given by

$$
\begin{aligned}
\operatorname{Pr} & {\left[X>X_{R}^{*} \equiv\left(\frac{(1+i)}{(1+r)(1-q)}\right) K_{R}^{*}+\left(\frac{r-i-q(1+r)}{(1+r)(1-q)}\right) L\right] } \\
& =\frac{\rho-i}{c_{R}}\left(\frac{(1+r)(1-q)}{(1+i)}\right)
\end{aligned}
$$

where $0<\frac{\rho-i}{c_{R}}\left(\frac{(1+r)(1-q)}{(1+i)}\right)<1$ and for a given distribution of $X$, the equilibrium probability of regulatory breach is increasing in $\rho$ and $r$ and decreasing in $q, i$, and $c_{R}$.

Proof. See Appendix A.

We can see from the right-hand side of (12) that the demand for bank capital now depends on the cost of capital, the deposit rate, the cost per dollar of regulatory capital deficiency, the market loan rate and the minimum capital ratio. It is reasonably straightforward to verify that the result in Corollary 2 remains valid with the introduction of capital requirements. In addition to the 
comparative static results of Corollary 2, by inspection of equation (12) we have:

Corollary 4 (Capital Requirements and the Demand for Capital). In addition to the comparative statics presented in Corollary 2, we also have that the demand for equity capital is increasing in $q$ and $c_{R}$. That is, $\frac{\partial K_{R}^{*}}{\partial q}>0, \frac{\partial K_{R}^{*}}{\partial c_{R}}>0$.

Proof. See Appendix A.

This result is intuitively appealing; if regulators impose a higher cost per dollar of deficiency or more stringent regulatory requirements on banks, then all things equal, banks will be more prone to breaching regulatory guidelines and subject to the costs associated with breach. This increases the expected costs of regulatory breach and therefore it is optimal for banks to reduce the equilibrium probability of regulatory breach and increase their demand for equity capital.

\section{i. Precautionary regulatory capital}

This model proves particularly useful in understanding bank holdings of capital in excess of what is officially required by regulators. Recall we have assumed that the bank - well, at least the manager of regulatory capital - has an unbiased view of the random process leading to loan losses and therefore has an unbiased expectation of the value of loan losses at the end of the period, $E(X)$. For this section, it is useful to rewrite (12) in the following fashion:

$$
\operatorname{Pr}\left[X-E(X)>X_{R}^{*}-E(X)\right]=\frac{\rho-i}{c_{R}}\left(\frac{(1+r)(1-q)}{(1+i)}\right)
$$

The right-hand side of the inequality in (13) gives the expected value of excess or precautionary regulatory capital, that is, capital that is held over and above what is required by regulatory guidelines. Note that for there to be expected precautionary capital, we require that $X_{R}^{*}>E(X)$; otherwise, there is an expected deficiency in regulatory capital and therefore an expectation that the bank will breach minimum regulatory requirements. If we assume that $f(X)$ is a symmetrical distribution, we can infer that in order for banks to hold precautionary regulatory capital, the equilibrium probability of regulatory breach must be less than one-half, that is, $\frac{\rho-i}{c_{R}}\left(\frac{(1+r)(1-q)}{(1+i)}\right)<\frac{1}{2}$. On the other hand, if $\frac{\rho-i}{c_{R}}\left(\frac{(1+r)(1-q)}{(1+i)}\right)>\frac{1}{2}$ then banks will be expected to have a deficiency in regulatory capital. Finally, if the optimal probability of regulatory breach is equal to one-half, then the bank will choose $K_{R}^{*}$ such that $X_{R}^{*}-E(X)$ is zero and be expected to hold the exact amount of capital required. Of course, actual precautionary capital or capital deficiency will depend on the value of $X$ that actually occurs.

The expected value of precautionary capital, if any, is given by the partial expectation of $X$ over the range of $X$ that would lead to expected precautionary 
capital, while the expected value of capital deficiency, if any, is the partial expectation of $X$ over the range of $X$ that would lead to an expected capital deficiency. ${ }^{5}$ The preceding discussion can be summarized in the following proposition:

Proposition 3 (Expected Precautionary Regulatory Capital). Let $F(X)$ denote the distribution of $X$, where $\frac{d F(X)}{d X}=f(X)$, and let $\Phi=\frac{\rho-i}{c_{R}}\left(\frac{(1+r)(1-q)}{(1+i)}\right)$ then

1. If $\Phi=\frac{1}{2}, K_{R}^{*}$ is chosen such that $X_{R}^{*}-E(X)=0$ and banks are expected to hold the exact amount of regulatory capital required.

2. If $\Phi<\frac{1}{2}, K_{R}^{*}$ is chosen such that $X_{R}^{*}-E(X)>0$ and banks are expected to hold precautionary regulatory capital with an expected value of

$$
X_{R}^{*} F\left(X_{R}^{*}\right)-\left[\frac{L}{4}+\int_{\frac{L}{2}}^{X_{R}^{*}} F(X) d X\right]>X_{R}^{*}-\left[\frac{L}{2}+2 \int_{\frac{L}{2}}^{X_{R}^{*}} F(X) d X\right]
$$

3. If $\Phi>\frac{1}{2}, K_{R}^{*}$ is chosen such that $X_{R}^{*}-E(X)<0$ and banks are expected to have a deficiency in regulatory capital with an expected value of

$$
\frac{L}{4}+\int_{\frac{L}{2}}^{X_{R}^{*}} F(X) d X-X_{R}^{*} F\left(X_{R}^{*}\right)>\frac{L}{2}+2 \int_{\frac{L}{2}}^{X_{R}^{*}} F(X) d X-X_{R}^{*}
$$

\section{Proof. See Appendix A.}

This result provides us with conditions under which we would expect banks to hold capital in excess of what is officially required. The model serves well in explaining the observed phenomena of nonbinding capital requirements. We see that so long as the equilibrium probability of regulatory breach is sufficiently low (less than one-half), then banks are expected to hold a buffer of capital over and above regulatory guidelines to avoid the expected costs associated with regulatory breach. The next section goes on to explore questions that are of potential relevance to the current policy debate on capital requirements.

\section{ii. Some policy considerations}

Recall from Corollary 3 that the equilibrium probability of breach depends on the deposit rate, the market rate for loans, the cost of capital, the minimum regulatory capital requirement and the cost per dollar of regulatory capital deficiency. Of these factors, two are under the direct control of regulators - the minimum regulatory capital requirement and the regulatory cost per dollar of capital deficiency. Given that minimum capital requirements are today removed from the domain of national regulators and are largely determined within the Basel Committee framework, the only real policy instrument available to national regulators hoping to influence banking behavior is 'regulatory pressure' or the severity of regulatory sanction if capital require-

5 See Winkler et al. (1972) for more on partial moments. 
ments are breached. In the current framework, the idea of regulatory pressure or severity of sanction can be captured generally by the regulatory cost per dollar of capital deficiency, $c_{R}$.

A higher cost per dollar of capital deficiency can be viewed as a higher degree of regulatory pressure or severity of ex-post sanction in the event of breach. It is clear from Corollary 3 and Proposition 3 that a higher $c_{R}$ is associated with a lower equilibrium probability of breach and thus a higher expected value of precautionary capital. ${ }^{6}$ It is therefore useful to look at some possible policy prescriptions with reference to the cost per dollar of regulatory capital deficiency.

Lemma 1 (Precautionary Capital and the Cost per Dollar of Breach). Denote the equilibrium probability of bankruptcy given by (7) to be $\Psi=\frac{\rho-i}{c}\left(\frac{1+r}{1+i}\right)$. Then, for the equilibrium probability of regulatory breach to be less than half such that banks are expected to hold precautionary capital, we require that

$$
c_{R}>2 \Psi c(1-q)
$$

Proof. See Appendix A.

This result follows directly from setting the right-hand side of (12) to be less than one-half and rearranging. If regulators desire banks to hold an expected buffer of capital above official requirements, then this result tells us that there is a minimum level of ex-post 'severity' that will induce banks to hold a buffer of free capital ex-ante. The next result follows by construction of the model:

\section{Lemma 2 (Equilibrium Probability of Bankruptcy and Regulatory Breach).}

1. In equilibrium, the loan loss threshold for bankruptcy is always at least as large as the loan loss threshold for regulatory breach, that is $\hat{X}^{*} \geq X_{R}^{*}$. Correspondingly, the equilibrium probability of regulatory breach is always at least as large as the equilibrium probability of bankruptcy.

2. Because the equilibrium probability of regulatory breach is always at least as large as the equilibrium probability of bankruptcy, it must be the case that

$$
c_{R} \leq c(1-q)
$$

6 The positive relationship between $c_{R}$ and the expected value of precautionary capital is clear from equation (A13) in the appendix. Corollary 4 tells us that $\frac{\partial K_{R}^{*}}{\partial c_{R}}>0$, and we know that $\frac{\partial X_{R}^{*}}{\partial K_{R}^{*}}>0$; thus, $\frac{\partial X_{R}^{*}}{\partial c_{R}}>0$. It follows that the expected value of precautionary capital $\int_{\frac{L}{2}}^{X_{R}^{*}} X F(X) d X$ is increasing in $c_{R}$. 
Proof. See Appendix A.

Lemma 2 tells us that by construction, the equilibrium probability of regulatory breach is always at least as large as the equilibrium probability of bankruptcy and therefore places an upper limit on the cost per dollar of regulatory capital deficiency. Given these results, can we identify conditions under which regulation can be viewed as 'effective.'

\section{Proposition 4 ('Effective' Policy).}

Effective regulation of banks requires that the per dollar cost of regulatory breach, $c_{R}$, satisfy the following condition:

$$
2 \Psi c(1-q)<c_{R} \leq c(1-q)
$$

which implies that the equilibrium probability of bankruptcy will be less than one-half and we expect the bank to survive.

Proof. See Appendix A.

If the goal of regulatory authorities is to prevent banking failure - more precisely, reduce the probability of bankruptcy so that the bank is expected to survive - then the previous result tells us that, ceteris paribus, regulators should set the cost per dollar of deficiency above some minimum up to the maximum allowable by construction. Note, however, that 'effective' regulation in the sense that it reduces the equilibrium probability of bankruptcy does not necessarily mean optimal regulation. One can think of regulators as choosing $c_{R}$ to maximize their own objective function, which we have no prior reason for believing coincides with some social welfare function that an omniscient and benevolent regulator aims to maximize. Optimality of regulation requires an analysis of the trade-offs between achieving financial soundness and potential efficiency losses from regulation, which this paper does not address. ${ }^{7}$

We have demonstrated that for regulation to be effective in the presence of a predetermined minimum capital standard such as those set out by the Basel Accord, the severity of ex-post sanction (value of $c_{R}$ ) in the event of breach needs to be set above some minimum.

It has already been mentioned that the buffer of precautionary capital is positively related to the severity of ex-post sanction. That is, as the cost per dollar of deficiency increases so does the expected value of precautionary capital. With this in mind, is this fact not only a potential explanation for observing nonbinding regulatory requirements but also an explanation for the large cross-national differences in the capital ratios? It is clear from Table 1 as well as the evidence presented in Bernauer and Koubi (2002) that banks in the United States and United Kingdom tend to hold more precautionary capital than European and Japanese banks. Moreover, this trend has continued, and for the time period beyond that reported in Table 1, we have seen an even greater

7 The interested reader should refer to Santomero and Watson (1977) and Giammarino et al. (1993) for discussion on the optimality of regulation. 


\section{Capital Requirements in Banking}

divergence in these cross-national capital ratios. Can the possible explanation for this simply be that US and UK regulators are stricter in the sense that they are less forbearing or impose more severe penalties in the event of regulatory breach? This question is difficult to answer in a theoretical inquiry and requires a detailed empirical analysis, which itself is not an easy task mainly due to the difficulty associated with measuring 'regulatory pressure' or severity of ex-post sanctions (Marcus 1983). Nevertheless, is there reason to suspect that US and UK regulators are less forbearing today relative to regulators in Europe and Japan? We argue yes and provide anecdotal evidence, which, although far from definitive, is at least suggestive below. However, before this a few slight extensions to the model are developed and discussed briefly in the next section.

\section{B. Extensions}

\section{i. The cost of deposits}

Producing and maintaining demand deposits requires a real resource expense to the bank. Up to this point, we have assumed for simplicity that these costs were zero. We can introduce a simple cost function $C(D)$ where $C_{D}>0$ and $C_{D D}>0$ as an explicit representation of this element. The critical value of $X$ above which bankruptcy occurs - equation (3) - then becomes

$$
X>\left(\frac{1+i}{1+r}\right) K+\left(\frac{r-i}{1+r}\right) L-C(D) \equiv \hat{X}
$$

Thus, the critical value of $X$ in the model with capital requirements - equation (8) - becomes:

$$
X>\left(\frac{(1+i)}{(1+r)(1-q)}\right) K+\left(\frac{r-i-q(1+r)}{(1+r)(1-q)}\right) L-\frac{C(D)}{(1-q)} \equiv X_{R}
$$

The profit function is now given by

$$
\Pi=r \int_{0}^{L}(L-X) f(X) d X-i D-\rho K-R-C(D)
$$

Consequently, the condition for optimality is

$$
-R_{K}=\rho-\left(i+C_{D}\right)
$$

where $R_{K}=\frac{\partial R}{\partial K}=-c_{R} \int_{X_{R}}^{L}\left(\frac{(1+i)}{(1+r)(1-q)}+\frac{C_{D}}{(1-q)}\right) f(X) d X .^{8}$

As we can see, the inclusion of an explicit cost function does not change the results significantly. The interpretation of the optimality condition still remains that banks should continue to issue equity until the marginal benefit of a reduction in the expected costs of regulatory breach is equal to the marginal cost of holding more expensive capital. The only difference now is that with the introduction of the cost function, ceteris paribus, banks will tend to hold more capital in equilibrium relative to the model with no explicit cost function

8 Note that $C_{D}=-C_{K}$ because the balance sheet constraint requires that $L=D+K$. 
because, for some given increase in capital, the decline in expected costs of regulatory breach is higher and the additional cost of holding more capital is lower.

\section{ii. The cost of capital}

Up till now, we have assumed that banks face a perfectly elastic supply of capital such that they have access to an infinite supply of capital at some constant cost. Some authors (e.g., Mingo and Wolkowitz 1977) suggest that this assumption may be unrealistic and assume that banks face an upward-sloping supply of capital function and so a bank cannot issue new equity without incurring an increasing cost of capital. With this consideration in mind, we can represent the cost of capital as $\rho=\rho(K)$ with $\rho_{K}>0$ and $\rho_{K K}>0$.

\section{iii. The deposit rate}

As with the cost of equity capital, we have assumed previously that banks face a perfectly elastic supply of deposits. Consequently, banks paid out a nominal constant interest rate for all deposits that is independent of the banks' chosen equity-deposits ratio. As pointed out by Baltensperger (1980), with the existence of expected costs of regulatory breach (and bankruptcy) this assumption does not seem justified. The possibility of regulatory breach (or bankruptcy) implies that the expected return on deposits will be less than the nominal return paid by banks. Thus, given some nominal deposit rate, the expected deposit rate is a function of the level of deposits - a higher level of deposits lowers the expected deposit rate. Note, however, that in a competitive banking system, banks will offer depositors a compensating adjustment in the nominal deposit rate whenever the expected deposit rate is lowered due to an increase in deposits. To incorporate these ideas into the framework, we let the deposit rate be a function of the level of deposits $i=i(D)$ with $i_{D}>0$ and $i_{D D}>0$.

Ignoring again the resource costs of producing and maintaining demand deposits, we can incorporate the idea of an increasing cost of capital and an increasing deposit rate into the profit function quite simply.

$$
\Pi=r \int_{0}^{L}(L-X) f(X) d X-i(D) D-\rho(K) K-R
$$

The first-order condition yields the following result:

$$
-\left(R_{K}+i_{D} D\right)=\rho-i+\rho_{K} K
$$

where $R_{K}=\frac{\partial R}{\partial K}=-c_{R} \int_{X_{R}}^{L}\left(\frac{(1+i)+i_{D}(L-K)}{(1+r)(1-q)}\right) f(X) d X$. Once again, allowing for an increasing cost of capital and increasing deposit rate yields a similar condition for optimality as (11). The interpretation remains the same - banks should continue to issue equity until the marginal benefit from doing so equals the marginal cost. Here, the marginal benefit is the reduction in expected costs associated with regulatory breach $-R_{K}$ plus the reduction in interest costs for all infra-marginal deposits $-i_{D} D$ as a result of holding less deposits and more capital. The marginal cost is now not only the additional cost of capital over and above the deposit rate $(\rho-i)$ of holding an extra increment of capital but also 
the increase in cost of all infra-marginal equity held, $\rho_{K} K$. It is difficult to say whether in equilibrium, the introduction of increasing capital and interest costs will lead to a higher or a lower level of capital relative to the baseline model. Introducing an increasing cost of capital increases the marginal cost of capital but leaves marginal benefit unchanged and so would induce banks to hold less capital. On the other hand, having increasing interest costs increases the marginal benefit of holding more capital but leaves the marginal cost unchanged and so would lead banks to hold more capital in equilibrium. Thus, the net result is uncertain.

\section{A SHRED OF EVIDENCE}

Those studying international banking regulation have argued that capital regulations impose substantial costs on banks; thus, the preferences and behavior of both regulators and banks are strongly shaped by a 'level playing field' or rent-seeking logic (see, e.g., Oatley and Nabors 1998). Yet, if compliance with capital adequacy requirements were very costly and thus affected the domestic and international competitiveness of banks, why do banks hold capital in excess of regulatory requirements? And why do national regulators continue to tolerate the large variations in cross-national capital ratios if the aim of the Basel Accord was to provide a level playing field by harmonizing capital standards?

It has been argued in this paper that part of the reason, we observe banks holding precautionary capital is to avoid the expected costs associated with regulatory breach. We have also suggested that the reason for the observed variations in cross-national capital ratios is due to cross-national differences in regulatory pressure or severity of sanction when capital guidelines are breached. The data reveal that US and UK banks hold substantially more precautionary capital than European or Japanese banks and the predictions of the model imply that this is because US and UK regulators are less forbearing than regulators in Europe or Japan. This section aims to provide evidence for why this may be the case and argues that the stringency of regulatory authorities in the United States today relative to their counterparts in Europe and Japan is a result of political pressure on regulatory authorities to 'keep the banks in check' after a de facto bailout for US banks was granted by US Congress in the aftermath of the Latin American debt crises. A similar story can be told for the United Kingdom but we do not provide it in the present paper. That is, we argue that banks are simply paying the price now - in terms of less regulatory forbearance for the bailout they received in the early 1980s.

\section{A. Trouble in paradise: weakness in US banks}

Loans to developing countries - like those in Latin America - are high risk because they carry a high chance of default. Losing assets due to default will eat 
Table 2 LDC exposure of commercial banks 1988

\begin{tabular}{lc}
\hline Country & Exposure (\% of capitalization) \\
\hline United States & $93-199$ \\
United Kingdom & $27-82$ \\
Japan and Europe & Under 55 \\
\hline
\end{tabular}

Note: The following table presents data on the exposure of G-10 commercial banks to less developed countries' (LDC) borrowers in 1988. Exposure is calculated as [(loans to LDCs/ capitalisation) $\times 100$ ]. The data clearly show an uneven pattern. US banks were the most exposed, with the ratio of exposure to developing country risk being between $93 \%$ for the least vulnerable banks and the most exposed at almost twice their capitalization.

Source: de Carmoy (1990).

into banks' capital reserves; thus, those who have low capital reserves relative to exposure would be most likely to fail. We thus turn our attention to data on the exposure of G-10 commercial banks to less developed countries' (LDC) borrowers and capital asset ratios.

Data on LDC exposure (Table 2) show an uneven pattern. US banks were the most exposed, with the ratio of exposure to developing country risk calculated according to the banks' capitalization being between 93\% for the least vulnerable banks and the most exposed at almost twice their capitalization. In 1987, the top 200 banks in the United States had some $\$ 30$ billion in reserves for default on LDC loans. The losses on LDC loans recorded by the six leading American banks that eventuated were so large that they were only offset by the 1987 gains of the United State's 70 other largest banks (de Carmoy 1990). British, European, and Japanese banks were much less exposed. For British banks, the margin was $27-82 \%$ of capitalization. Japanese and European banks were in a much stronger position, with a ratio below 55\%. Thus, only American banks were exposed above capitalization.

Examination of provisions for default and banks' shareholder equity for various countries (Tables 3 and 4) reveals that American banks, who were involved in very risky lending activities, have considerably higher capital-toasset and equity-to-asset ratios than the Japanese, who for tax purposes - and considering the quality of their commercial loans and the size of hidden reserves of security and real estate - had a particularly low level of equity and provisions for doubtful loans. British banks' situation appears to be closer to that of the United States than to Japan.

The important point to note is that the pattern in capital-to-asset and equityto-asset ratios is consistent with the lending portfolios of the banks - American and British banks, holding riskier portfolios due to a higher concentration of loans to LDCs, were carrying more capital than the less exposed Japanese and European banks. The data indicate a severe weakness in US commercial banks (Oatley and Nabors 1998).

As a result, any negative shock to the Latin American countries will have significantly larger adverse consequences for US and UK banks in comparison 
Table 3 Capital assets ratios of G-10 banks, 1981-1989

\begin{tabular}{lccccccccc}
\hline Bank & 81 & 82 & 83 & 84 & 85 & 86 & 87 & 88 & Average \\
\hline European Banks & & & & & & & & & \\
$\quad$ Banque Nationale de Paris & 1.28 & 1.34 & 1.53 & 1.51 & 1.98 & 3.15 & 3.17 & 2.83 & 2.10 \\
Banque Bruxelles Lambert & 1.81 & 1.49 & 1.68 & 1.55 & 1.61 & 2.10 & 2.04 & 2.10 & 1.80 \\
$\quad$ Dresdner Bank & 2.93 & 2.88 & 2.68 & 2.66 & 2.82 & 3.24 & 3.23 & 3.30 & 2.97 \\
Allgemeine Bank & 2.37 & 2.52 & 2.75 & 2.67 & 2.91 & 3.51 & 3.96 & 3.68 & 3.05 \\
Deutsche Bank & 3.10 & 3.27 & 3.24 & 3.33 & 3.99 & 3.93 & 4.06 & 3.78 & 3.59 \\
Banca Nazionale del Lavoro & 3.85 & 3.84 & 2.88 & 4.11 & 4.70 & 5.39 & 3.80 & 3.80 & 4.05 \\
Barclays & 4.66 & 4.68 & 4.56 & 3.53 & 5.07 & 4.71 & 4.83 & 5.57 & 4.70 \\
$\quad$ Union des Banques Suisse & 5.67 & 5.14 & 4.97 & 5.09 & 5.78 & 5.71 & 6.08 & 6.10 & 5.57 \\
American Banks & & & & & & & & & \\
$\quad$ Citicorp & 3.80 & 3.98 & 4.58 & 4.50 & 4.64 & 4.73 & 4.33 & 4.84 & 4.43 \\
$\quad$ Bank of America & 3.54 & 3.97 & 4.45 & 4.50 & 3.96 & 3.39 & 3.59 & 4.45 & 3.98 \\
$\quad$ Chase Manhattan & 4.77 & 4.26 & 4.75 & 4.93 & 5.25 & 5.37 & 3.31 & 4.34 & 4.62 \\
Japanese Banks & & & & & & & & & \\
$\quad$ Sumitomo & 3.13 & 2.95 & 2.96 & 2.25 & 2.85 & 2.95 & 2.20 & 2.55 & 2.73 \\
Dai Ichi Kangyo & 3.26 & 2.86 & 2.63 & 2.51 & 2.38 & 2.38 & 1.79 & 2.75 & 2.57 \\
Fuji & 3.51 & 3.00 & 2.98 & 2.82 & 2.82 & 2.89 & 2.20 & 2.75 & 2.87 \\
\hline
\end{tabular}

Note: The following table presents data on the capital-assets-ratios [total capital/total assets] for selected G-10 banks between 1981 and 1989. The figures presented are percentages. The data reveal that American banks, who were involved in very risky lending activities (see Table 2), have considerably higher capital-to-asset ratios than the Japanese, who for tax purposes - and considering the quality of their commercial loans and size of hidden reserves of security and real estate - had a particularly low level of equity and provisions for doubtful loans. British banks' situation appears to be closer to that of the United States than to Japan.

Source: de Carmoy (1990).

with banks in Japan and Europe. Table 5 demonstrates this point by presenting data on American bank failures between 1981 and 1988; it shows a sharp increase in bank failures in 1983 in the wake of the Latin American debt crises and a steady increase there on in. Out of a total of approximately 14,000 banks, 644 (4.6\%) went bankrupt between 1985 and 1988. Over the same period no Japanese banks went insolvent while the number of European banks that failed was significantly less than in the United States.

\section{B. The latin American debt crisis bailout}

In 1982-1983, there was a sudden intensification of external economic pressures on the US banking system that proved to be the catalyst for the decisive resolution of the capital adequacy issue at the domestic level. To be precise, it was the materialization of the industrializing countries' debt crises in 1982 that exposed the insufficiency of capital reserve levels of the US multinational banks to buffer against such external shocks. This led to concerns that imprudent lending practices by these banks were undermining the stability of the entire US banking system. At the same time, Congress - which was, up till 
Table 4 Equity to assets ratios of G-10 banks, 1983-1988

\begin{tabular}{lccccccc}
\hline Banks & 83 & 84 & 85 & 86 & 87 & 88 & Average \\
\hline Japanese Banks & & & & & & & \\
Dai Ichi Kangyo & 2.63 & 2.51 & 2.38 & 2.38 & 1.79 & 2.41 & 2.35 \\
Sumitomo & 2.96 & 2.25 & 2.85 & 2.95 & 2.20 & 2.55 & 2.63 \\
Fuji & 2.98 & 2.83 & 2.82 & 2.89 & 2.20 & 2.55 & 2.71 \\
Mitsubishi & 2.83 & 2.85 & 2.88 & 2.99 & 2.14 & 2.58 & 2.71 \\
Sanwa & 2.78 & 2.67 & 2.70 & 2.61 & 1.96 & 2.46 & 2.53 \\
Industrial Bank of Japan & 2.33 & 2.38 & 2.84 & 2.80 & 2.43 & 3.12 & 2.65 \\
Norinchukin Bank & 0.46 & 0.50 & 0.47 & 0.47 & 0.52 & 0.55 & 0.50 \\
Mitsubishi Trust \& Banking & 0.23 & 2.18 & 2.06 & 2.22 & 2.34 & 3.08 & 2.02 \\
Tokai & 0.45 & 2.51 & 2.65 & 2.60 & 1.62 & 2.38 & 2.04 \\
Sumitomo Trust \& Banking & 0.28 & 2.34 & 2.15 & 2.29 & 1.43 & 1.80 & 1.72 \\
Mitsui & 2.41 & 2.43 & 2.36 & 2.52 & 1.88 & 1.32 & 2.15 \\
Long-Term Credit Bank of Japan & 0.47 & 2.08 & 2.05 & 2.11 & 2.37 & 2.93 & 2.00 \\
American Banks & & & & & & & \\
Citicorp & 4.58 & 4.50 & 4.64 & 4.73 & 4.33 & 4.84 & 4.60 \\
Chase Manhattan & 4.75 & 4.93 & 5.25 & 5.37 & 3.31 & 4.34 & 4.66 \\
Bank of America & 4.45 & 4.50 & 3.96 & 3.39 & 3.59 & 4.45 & 4.06 \\
European Banks & & & & & & & \\
Crédit Agricole & 4.24 & 4.15 & 4.26 & 4.36 & 4.43 & 4.08 & 4.25 \\
Banque Nationale de Paris & 1.53 & 1.51 & 1.98 & 3.15 & 3.17 & 2.83 & 2.36 \\
Deutsche Bank & 3.24 & 3.33 & 3.99 & 3.93 & 4.06 & 3.78 & 3.72 \\
Crédit Lyonnais & - & 1.14 & 1.23 & 1.91 & 2.64 & 3.02 & 1.99 \\
Barclays & 4.56 & 3.53 & 5.07 & 4.71 & 4.89 & 5.57 & 4.72 \\
National Westminster & 4.79 & 3.68 & 4.10 & 5.54 & 5.70 & 6.11 & 4.99 \\
Société Genéralé & 1.32 & 1.36 & 2.03 & 2.90 & 3.23 & 3.35 & 2.37 \\
Midland & 3.61 & 2.74 & 3.18 & 3.80 & 5.34 & 5.45 & 4.02 \\
\hline
\end{tabular}

Note: The following table presents data on the equity-to-assets ratios [total equity/total assets] for selected G-10 banks between 1983 and 1988. The figures presented are percentages. The data reveal that American banks, who were involved in very risky lending activities (see Table 2), have considerably higher equity-to-asset ratios than the Japanese, who for tax purposes - and considering the quality of their commercial loans and size of hidden reserves of security and real estate - had a particularly low level of equity and provisions for doubtful loans. British banks' situation appears to be closer to that of the United States than to Japan.

Source: de Carmoy (1990).

this point, relatively laissez faire with regard to capital adequacy - began to mobilize and enter the capital adequacy debate.

Word began to spread in the early part of 1982 that the International Monetary Fund's (IMF) resources were considerably strained by a number of financial problems in Latin American debtor countries. These rumors came to fruition in August of 1982 when Mexico announced that it would not be able to meet their financial obligations on debts totaling $\$ 81$ billion USD, of which, $\$ 23$ billion USD was owed to US multinationals. The problem was exacerbated in November and December when, first, Argentina declared that it was experiencing financial difficulty and second, Brazil notified its creditors that it would not be able to honor payments due on an external debt exceeding $\$ 79$ 
Table 5 American bank failures, 1981-1988

\begin{tabular}{lc}
\hline Year & Number of failures \\
\hline 1981 & 10 \\
1984 & 79 \\
1985 & 120 \\
1986 & 160 \\
1987 & 184 \\
1988 & 180 \\
\hline
\end{tabular}

Note: The table presents data on American bank failures between 1981 and 1988, it shows a sharp increase in bank failures in 1983 in the wake of the Latin American debt crises and a steady increase there on in. Out of a total of approximately 14,000 banks, 644 (4.6\%) went bankrupt between 1985 and 1988.

Source: de Carmoy (1990).

billion USD. In short, by the middle of 1982, the nine largest banks in the United States had lent over $140 \%$ of their capital, which totaled to loans of $\$ 30$ billion USD to these three countries alone (Reinke 1995).

Following this, a meeting of the IMF member countries agreed that an increase in IMF resources was desperately needed, which culminated in 1983 with a planned increase of IMF resources by $47 \%$ or approximately $\$ 32$ billion USD, of which, the US share - which needed the approval of Congress - was in the order of $\$ 8.4$ billion USD. The fact that the rescue package required Congressional approval meant that Congress was in a strong position when it came to the bargaining table with the three regulatory authorities and commercial banks. ${ }^{9}$

At the time, America was experiencing one of the worst recessions since World War 2, and so even before legislation authorizing the funds was sent to Capitol Hill by the Reagan Administration, there was strong opposition against the IMF quota increase (Reinke 1995). The general consensus was that the IMF quota increase was nothing but a sophisticated de facto bailout for the big US banks. In the words of Ferdinand St. Germain, chairman of the House Banking Committee:

[A]t a time when millions stand in unemployment lines and thousands of small businesses are filing bankruptcy petitions, the idea of an international

9 The three federal regulatory bodies are the Office of Comptroller of the Currency (OCC), the Federal Reserve (Fed) and the Federal Deposit Insurance Corporation (FDIC). Unlike Australia, where banking regulation and supervision is carried out by a single federal regulatory body: the Australian Prudential Regulation Authority (APRA), US banking regulation is decentralized. One of the principal characteristics of the US regulatory structure is the dual banking system. This allows banks to charter at either the federal or at the state level. The result is that there are 50 state legislatures that have decision-making authority. The state regulatory agencies are represented in Washington by the Conference of State Bank Supervisors, which monitors all federal regulatory activity that could in any way intrude on their regulatory power. For a more detailed examination of the US regulatory structure, see Reinke (1995). 
bailout for adventurous U.S. bankers may not be the most popular item on the agenda. ${ }^{10}$

Despite this, the Reagan administration, regulatory authorities and the private banks continued to push their agenda. They argued that not approving an increase in IMF resources would lead to a financial disaster for the heavily exposed multinational banks, which would ultimately lead to domestic and international crises not only in the financial sector but also the real economy because a credit crunch would be the most likely outcome if the Latin American countries defaulted (Reinke 1995). Members of Congress were well aware of the dilemma facing them, as Senator Jim Sasser put it:

I think it is a Hobson's choice. We are damned if we do and damned if we don't. ${ }^{11}$

Faced with this quandary, Congress realized that they would have to eventually yield to political pressure and approve the IMF quota increase. Nevertheless, they wanted to minimize the political backlash from their constituencies and were adamant to attach amendments to the IMF quota increase vis-a-vis the behavior of commercial banks and extort credible commitments from both the regulatory agencies and the banks that such a 'bailout' would not be repeated. During the course of hearings on the quota increase, Congress shifted its attention from the banks to the regulators; the feeling in Congress toward the regulators was probably best captured by Senator William Proxmire, who, in a hearing in early 1983, remarked:

Where were our bank regulators when all this foreign debt was piling up? ... They did everything except regulate. ${ }^{12}$

While making some concessions, the regulators were generally reluctant to take the blame for the debt crisis. Chairman of the Federal Reserve at the time, Paul Volker, judged that the basic framework of the system introduced in 1979 was sound and warned Congress not to overreact with excessive regulations; further, he had this to say in response to the criticisms of Congress:

[I]n the past decade there has been a view by some of the banking community that capital is irrelevant, and that one shouldn't worry about capital ratios, and that capital ratios declining are not very important. ${ }^{13}$

The federal regulators put on a united front in reaction to Congress and agreed in principle that capital standards of the large multinational banks should be strengthened; however, still defied congressional calls for more

10 As quoted in Reinke (1995, p. 143).

11 Reinke (1995).

12 As quoted in Reinke (1995, p. 144).

13 Reinke (1995, p. 144). 
stringent regulation on the grounds that capital supervision was a matter concerning the regulators and not Congress. More to the point, the regulators were sympathetic to the calls of the money center banks that stricter capital regulations will put them at an international competitive disadvantage, to illustrate; Paul Volker had this to say to the legislature:

[B]anks undoubtedly have felt under very heavy pressure internationally, and carrying more capital is costly. ${ }^{14}$

To prevent any further intervention by Congress and to accelerate the IMF quota increase, the three regulatory agencies presented to Congress a five-point program to strengthen the supervision of international lending. This program however, did not contain any specific policy proposal with regard to capital adequacy; rather, the regulators agreed that their existing constitutional authority was sufficient to implement a new regulatory reform program independently without the need for any legislative action. The banks were opposed to the five-point regulatory program developed by the agencies to appease Congress and even more opposed to the possibility of legislative action by Congress, according to the vice chairman of Chase Manhattan Bank:

A tighter web of administrative controls around the foreign lending of banks, as some have suggested, would be unwise, unnecessary and counter productive. ${ }^{15}$

The discontent of the large multinational banks did not sit well with Congress, who argued that the money center banks shared considerable responsibility for the debt crises because of their imprudent behavior. Congress viewed the IMF quota increase as a bailout for the banks by the American tax payer, and thus argued that any increase in the US contribution must be accompanied by a tightening of capital standards to ensure that a recurrence of such a bailout would not occur (Reinke 1995).

Thus, up till this point, aside from some minor concessions made to Congress by the regulatory agencies, there appeared to be a stand-off between Congress and the regulators. However, a second event further shifted the balance of power toward Congress. Although the banks had previously lobbied against new and stricter requirements, none had formally challenged the regulatory authorities. This status quo was changed when in February of 1983, the First National Bank of Bellaire formally challenged the OCC's authority to impose explicit capital requirements and issue a 'cease-and-desist' order if banks did not comply. The First National Bank of Bellaire obtained a ruling in its favor in the courts of appeal. This ruling cast severe doubt over the regulatory agencies' authority and legitimacy to enforce capital standards and meant that the only way for the regulators to restore their institutional capacity was for Congress to step in and explicitly change legislation such that the federal regulators had the

14 Reinke (1995, p. 144).

15 As quoted in Reinke (1995, p. 145). 
authority to impose and enforce minimum capital standards. Congress now held all the bargaining chips and indicated that it was willing to provide such authority in return for a promise from the regulators that they will act on the concerns about financial stability and capital adequacy; the regulators had no choice but to submit to Congress, as Reinke (1995) put it:

Given the legislature's determination to go beyond what the regulatory agencies had initially proposed; the regulators' dependence upon Congress to enact legislation that would restore their credibility in establishing capital levels; and the urgency to get the IMF quota increase, the Fed, which had been most resistant to any specific ratios for [multinational banks], quickly acquiesced to Congress. ${ }^{16}$

The Senate was quick to respond to the pledge by the regulators to implement minimum capital ratios for multinational banks and approved a bill authorizing an $\$ 8.4$ billion increase in the US IMF contribution on June 8,1983 . The regulators kept their promise and on June 13, the Fed and the OCC released a series of changes to their earlier guidelines in order to bring multinational banks, which were previously largely excluded from, into line with other commercial banks under a uniform set of regulations. These amendments saw, for the first time, regulations that set explicit minimum capital ratios for multinational banks. Nevertheless, progress in the House was much slower; a lobbyist described the situation in the House well, suggesting that:

[N]obody, not one member of Congress, is going to win votes back home on this unless [Citibank Chairman] Wriston lives in their district. ${ }^{17}$

In spite of these concerns, the bill was narrowly approved on August 3, 1983, winning 217-211 (Reinke 1995). Finally, after further deliberation, in early November, the bill was approved and Congress passed the International Lending Supervisory Act (ILSA). This new act gave back to the regulators the capacity to ensure financial stability by empowering them with the ability to set and enforce capital adequacy standards. With their new powers, the three federal regulators were quick to act on strengthening capital adequacy standards and by April 1985, all three regulators agreed that minimum capital ratios should be set and enforced for all commercial banks.

\section{CONCLUSION}

Most models of banking behavior either ignore the capital decision for banks or assume that capital requirements are a binding constraint. This is largely inconsistent with what is observed in reality. A brief glance at the data reveals that banks tend to hold capital well in excess of what is required by regulatory guidelines.

16 Reinke (1995, p. 147).

17 As quoted in Reinke (1995, p. 148). 
This paper provides a model of bank financing decisions where the level of capital is determined within a profit-maximizing equilibrium. It is shown that optimality involves balancing the reduction in expected costs associated with regulatory breach with the excess cost of financing from increasing capital. The results also demonstrate that when the equilibrium probability of regulatory breach is less than one-half, banks are expected to hold a buffer of capital above official regulatory requirements - that is, banks are expected to hold precautionary capital.

Previous authors have suggested that 'market discipline' has been the driver behind the observed over-compliance with capital regulations. The idea that banks hold precautionary capital because of market incentives is quite reasonable. Nevertheless, given that the Federal safety net still exists, one would expect market incentives (while possibly improved with a weakening of the safety net over time) to remain somewhat stifled. Consequently, there must be another reason for observing nonbinding capital requirements. This paper therefore provides an alternative - although complementary - explanation as to why banks hold precautionary capital. It is likely that this phenomenon of nonbinding capital requirements can be explained by some combination of market discipline as well as what is proposed in this paper.

We also point to the large differences in cross-national capital ratios observed in the last decade and suggest that this may reflect varying degrees of crossnational regulatory forbearance. The implications of the model suggest that the fact that US and UK banks hold more precautionary capital than their counterparts in Europe and Japan implies that US and UK regulators must be more severe with punishment in the event of regulatory breach. We look at anecdotal evidence from the Unites States that is suggestive that one reason for believing that US regulatory authorities are relatively stringent is the result of political pressure from Congress to 'keep the banks in check' after the politically sensitive decision was made to provide a de facto bailout to US banks in the aftermath of the Latin American debt crises.

The results and implications of this paper provide new insights into the debate on capital and its adequacy. Although theory alone will not provide us with definitive answers, this paper points to the directions that future lines of empirical enquiry should take to advance our understanding of prudential regulation.

Phong T. H. Ngo

School of Finance and Applied Statistics

Australian National University

Crisp Building 026

ACT 0200

Australia

phong.ngo@anu.edu.au 


\section{REFERENCES}

Baltensperger, E. (1974), 'The Precautionary Demand for Reserves', American Economic Review, 64, 205-10.

Baltensperger, E. (1980), 'Alternative Approaches to the Theory of the Banking Firm', Journal of Monetary Economics, 6, 1-37.

Basel Committee on Banking Supervision (1999), 'Capital Requirements and Bank Behaviour: the Impact of the Basel Accord', Basel Committee on Banking and Supervision Working Paper No. 1, Bank for International Settlements.

Berger, A. N., R. J. Herring, and G. P. Szego (1995), 'The Role of Capital in Financial Institutions', Journal of Banking and Finance, 19, 257-76.

Bernauer, T., and V. Koubi (2002), 'Regulating Bank Capital: Can Market Discipline Facilitate or Replace Capital Adequacy Rules?', Center for International Studies Working Paper No. 3-2002, Swiss Federal Institute of Technology.

de Bondt, G. J., and H. M. Prast (1999), 'Bank Capital Ratios in the 1990s: Cross Country Evidence', Research Memorandum WO\&E no. 603/9936, De Nederlandsche Bank (The Dutch National Bank).

de Carmoy, H. (1990), Global Banking Strategy: Financial Markets and Industry Decay. UK: Basil Blackwell Ltd.

Dietrich, J. K., and C. James (1983), 'Regulation and the Determination of Bank Capital Changes: A Note', Journal of Finance, 38, 1651-8.

Flannery, M. J., and K. P. Rangan (2004), 'What Caused the Bank Capital Build-up of the 1990s?', Mimeo, University of Florida.

Furlong, F. T., and M. C. Keeley (1989), 'Capital Regulation and Bank Risk Taking: A Note', Journal of Banking and Finance, 13, 883-91.

Genschel, P., and T. Plumper (1996), 'Regulatory Competition and International Cooperation', Journal of European Public Policy, 4, 626-42.

Giammarino, R. M., T. R. Lewis, and D. Sappington (1993), 'An Incentive Approach to Bank Regulation', Journal of Finance, 48, 1523-42.

Kahane, Y. (1977), 'Capital Adequacy and the Regulation of Financial Intermediaries', Journal of Banking and Finance, 1, 207-18.

Kaufman, G. G. (1991), 'Capital in Banking: Past Present and Future', Journal of Financial Services Research, 5, 385-402.

Keeley, M. C. (1990), 'Deposit Insurance, Risk, and Market Power in Banking', American Economic Review, 80, 1183-200.

Kim, D., and A. M. Santomero (1988), 'Risk in Banking and Capital Regulation', Journal of Finance, 35, 1219-33.

Koehn, M., and A. M. Santomero (1980), 'Regulation of Bank Capital and Portfolio Risk', Journal of Finance, 35, 1235-50.

Marcus, A. J. (1983), 'The Bank Capital Decision: A Time Series - Cross Section Analysis', Journal of Finance, 38, 1217-32.

Milne, A. (2002), 'Bank Capital Regulation as an Incentive Mechanism: Implications for Portfolio Choice', Journal of Banking and Finance, 26, 1-23.

Milne, A., and E. Whalley (2001), 'Bank Capital and Incentives for Risk Taking', Working Paper, City University.

Mingo, J. (1975), 'Regulatory Influence on Bank Capital Investment', Journal of Finance, 30, 1111-21.

Mingo, J., and B. Wolkowitz (1977), 'The Effects of Regulation on Bank Balance Sheet Decisions', Journal of Finance, 32, 1605-16.

Ngo, P. T. H. (2006), 'The Relationship between Capital-Risk Decisions and Profitability in Banking', Mimeo, Australian National University.

Oatley, T., and R. Nabors (1998), 'Redistributive Cooperation: Market Failure, Wealth Transfers, and the Basel Accord', International Organization, 52, 35-54. 


\section{Capital Requirements in Banking}

Peltzman, S. (1970), 'Capital Investment in Commercial Banking and its Relation to Portfolio Regulation', Journal of Political Economy, 78, 1-26.

Pringle, J. J. (1974), 'The Capital Decision in Commercial Banks', Journal of Finance, 29, 779-95.

Poole, W. (1968), 'Commercial Bank Reserve Management in a Stochastic Model: Implications for Monetary Policy', Journal of Finance, 23, 769-91.

Reinke, W. H. (1995), Banking, Politics and Global Finance: American Commercial Banks and Regulatory Change, 1980-90. Vermont, USA: Edward Elgar Publishing.

Santomero, A. M., and R. D. Watson (1977), 'Determining an Optimal Capital Standard for the Banking Industry', Journal of Finance, 32, 1267-82.

Saunders, A., and B. Wilson (1999), 'The Impact of Consolidation and Safety-Net Support on Canadian, US and UK Banks: 1893-1992', Journal of Banking and Finance, 23, 537-71.

Winkler, R. L., G. M. Roodman, and R. R. Britney (1972), 'The Determination of Partial Moments', Management Science (Theory Series), 19, 290-6.

Zarruk, E., and J. Madura (1992), 'Optimal Bank Interest Margin under Capital Regulation and Deposit Insurance', Journal of Financial and Quantitative Analysis, 27, 143-9.

\section{APPENDIX A}

Proof of Proposition 1. Substituting the balance sheet constraint into (5) for $D$, differentiating with respect to $K$ and setting the result equal to zero yields the following necessary condition for an optimum:

$$
\frac{\partial \Pi}{\partial K}=i-\rho-B_{K}=0
$$

Or

$$
-B_{K}=\rho-i
$$

where $B_{K}=\frac{\partial B}{\partial K}=-c \int_{\hat{X}}^{L}\left(\frac{1+i}{1+r}\right) f(X) d X$. Note the sufficient condition for an interior solution is $B_{K K}=\frac{\partial^{2} B}{\partial K^{2}}>0$.

Proof of Corollary 1. (A2) implies

$$
c \int_{\hat{X}}^{L}\left(\frac{1+i}{1+r}\right) f(X) d X=\rho-i
$$

$\mathrm{Or}$

$$
\int_{\hat{X}}^{L} f(X) d X=\frac{\rho-i}{c}\left(\frac{1+r}{1+i}\right)
$$

where $\int_{\hat{X}}^{L} f(X) d X=\operatorname{Pr}\left[X>\hat{X}^{*} \equiv\left(\frac{1+i}{1+r}\right) K^{*}+\left(\frac{r-i}{1+r}\right) L\right]$. Also, let $\Psi=\frac{\rho-i}{c}\left(\frac{1+r}{1+i}\right)$, then $\frac{\partial \Psi}{\partial \rho}=\frac{1}{c}\left(\frac{1+r}{1+i}\right)>0, \frac{\partial \Psi}{\partial c}=-\frac{\rho-i}{c^{2}}\left(\frac{1+r}{1+i}\right)<0, \frac{\partial \Psi}{\partial i}=-\frac{1+\rho}{(1+i)^{2}}\left(\frac{1+r}{c}\right)<0, \frac{\partial \Psi}{\partial r}=\frac{\rho-i}{c}\left(\frac{1}{1+i}\right)>0$. That is, the equilibrium probability of bankruptcy is increasing in $\rho$ and $r$ and decreasing in $i$ and $c$.

Proof of Corollary 2. Recall from Corollary 1 that $\operatorname{Pr}\left[X>\hat{X}^{*} \equiv\left(\frac{1+i}{1+r}\right) K^{*}\right.$ $\left.+\left(\frac{r-i}{1+r}\right) L\right]=\frac{\rho-i}{c}\left(\frac{1+r}{1+i}\right) \equiv \Psi$. We know that the right hand side of this expression is increasing in $\rho$ and $r$ and decreasing in $i$ and $c$. Thus any changes in $\rho, r, i$, and $c$ 
must correspond with changes in $K^{*}$ to maintain equilibrium. Suppose $\partial \rho>0$, this leads to an increase in the optimal probability of bankruptcy which can only be achieved through a decrease in the optimal critical threshold $\hat{X}^{*}$ which, in turn can be achieved by reducing the optimal capital level $K^{*}$, that is $\frac{\partial K^{*}}{\partial \rho}<0$. This can also be shown more directly by considering the optimality condition given by (A1). Differentiating this with respect to $\rho$ yields the following

$$
\frac{\partial^{2} \Pi}{\partial K^{2}} \frac{\partial K}{\partial \rho}=-1+\frac{\partial^{2} B}{\partial K^{2}} \frac{\partial K}{\partial \rho}=0
$$

Solving for $\frac{\partial K}{\partial \rho}$ and noting $B_{K K}=\frac{\partial^{2} B}{\partial K^{2}}>0$ is required for an interior solution, we get

$$
\frac{\partial K}{\partial \rho}=-\frac{1}{\frac{\partial^{2} B}{\partial K^{2}}}<0
$$

Consider now an increase in $i$, that is $\partial i>0$. An increase in $i$ leads to a reduction in $\Psi$ which must be associated with a rise in $\hat{X}^{*}$. Moreover, note that a rise in $i$ leads to a reduction in $\hat{X}^{*}$, that is $\frac{\partial \hat{X}^{*}}{\partial i}=\frac{1}{1+r}\left(K^{*}-L\right) \leq 0$ since $K \in[0, L]$. Thus for $\hat{X}^{*}$ to increase with $i, K^{*}$ must unambiguously rise in response to an increase in $i$, in other words $\frac{\partial K^{*}}{\partial i}>0$. Once again, this result can be obtained directly from (A1). Differentiating (A1) with respect to $i$ we get:

$$
\frac{\partial^{2} \Pi}{\partial K^{2}} \frac{\partial K}{\partial i}=1-\frac{\partial^{2} B}{\partial K^{2}} \frac{\partial K}{\partial i}=0
$$

Solving for $\frac{\partial K}{\partial i}$ and recalling that $B_{K K}=\frac{\partial^{2} B}{\partial K^{2}}>0$ we get the desired result:

$$
\frac{\partial K}{\partial i}=\frac{1}{\frac{\partial^{2} B}{\partial K^{2}}}>0
$$

Let $\partial c>0$ which results in a decrease in $\Psi$. A decrease in $\Psi$ can only be achieved through a rise in $\hat{X}^{*}$ and therefore $K^{*}$, that is, $\frac{\partial K^{*}}{\partial c}>0$. Finally, suppose $\partial r>0$ causing an increase in $\Psi$ which must be associated with a fall in $\hat{X}^{*}$. Note also that $\frac{\partial \hat{X}^{*}}{\partial r}=\frac{1+i}{1+r}\left(L-K^{*}\right) \geq 0$ because $K \in[0, L]$ thus it must be the case the $K^{*}$ unambiguously decreases or $\frac{\partial K^{*}}{\partial c}<0$.

Proof of Proposition 2. Substituting the balance sheet constraint into (10) for $D$, differentiating with respect to $K$ and setting the result equal to zero yields the following necessary condition for an optimum:

$$
\frac{\partial \Pi}{\partial K}=i-\rho-R_{K}=0
$$

Or

$$
-R_{K}=\rho-i
$$

where $R_{K}=\frac{\partial R}{\partial K}=-c_{R} \int_{X_{R}}^{L}\left(\frac{(1+i)}{(1+r)(1-q)}\right) f(X) d X$. Note the sufficient condition for an interior solution is $R_{K K}=\frac{\partial^{2} R}{\partial K^{2}}>0$. 


\section{Capital Requirements in Banking}

Proof of Corollary 3. (A10) implies:

$$
c_{R} \int_{X_{R}}^{L}\left(\frac{(1+i)}{(1+r)(1-q)}\right) f(X) d X=\rho-i
$$

Or

$$
\int_{X_{R}^{*}}^{L} f(X) d X=\frac{\rho-i}{c_{R}}\left(\frac{(1+r)(1-q)}{(1+i)}\right)
$$

where

$$
\int_{X_{R}^{*}}^{L} f(X) d X=\operatorname{Pr}\left[X>X_{R}^{*} \equiv\left(\frac{(1+i)}{(1+r)(1-q)}\right) K_{R}^{*}+\left(\frac{r-i-q(1+r)}{(1+r)(1-q)}\right) L\right] .
$$

Also, let $\Phi=\frac{\rho-i}{c_{R}}\left(\frac{(1+r)(1-q)}{(1+i)}\right)$, then $\frac{\partial \Phi}{\partial \rho}=\frac{1}{c_{R}}\left(\frac{(1+r)(1-q)}{(1+i)}\right)>0, \quad \frac{\partial \Phi}{\partial c_{R}}=-\frac{\rho-i}{c_{R}^{2}}$ $\left(\frac{(1+r)(1-q)}{(1+i)}\right)<0, \quad \frac{\partial \Phi}{\partial i}=-\frac{1+\rho}{(1+i)^{2}}\left(\frac{(1+r)(1-q)}{c_{R}}\right)<0, \quad \frac{\partial \Phi}{\partial r}=\frac{\rho-i}{c_{R}}\left(\frac{1-q}{1+i}\right)>0$ and $\frac{\partial \Phi}{\partial q}=-\frac{\rho-i}{c_{R}}$ $\left(\frac{1+r}{1+i}\right)<0$. That is, for a given distribution of $X$, the equilibrium probability of regulatory breach is increasing in $\rho$ and $r$ and decreasing in $q, i$ and $c_{R}$.

Proof of Corollary 4. Recall from Corollary 3 that

$$
\begin{aligned}
& \operatorname{Pr}\left[X>X_{R}^{*} \equiv\left(\frac{(1+i)}{(1+r)(1-q)}\right) K_{R}^{*}+\left(\frac{r-i-q(1+r)}{(1+r)(1-q)}\right) L\right]=\frac{\rho-i}{c_{R}}\left(\frac{(1+r)(1-q)}{(1+i)}\right) \\
& \quad \equiv \Phi
\end{aligned}
$$

Suppose that regulators decide to impose more stringent capital requirements on banks, that is, $\partial q>0$. We have already shown that the optimal probability of regulatory breach is decreasing in $q$, therefore $\frac{\partial \Phi}{\partial q}<0$. We require an increase in the critical level of losses for there to be a fall in the optimal probability of regulatory breach. Moreover, note that the right hand side of the inequality within the square brackets is decreasing in $q$, in other words, $\frac{\partial X_{R}^{*}}{\partial q}=$ $\frac{1}{(1-q)^{2}}\left(\frac{1+i}{1+r}\right)\left[K_{R}^{*}-L\right] \leq 0$ because $K \in[0, L]$. Thus there must be an unambiguous rise in the demand for capital to ensure a reduction in the optimal probability if regulatory breach, that is $\frac{\partial K_{R}^{*}}{\partial q}>0$. The proof that $\frac{\partial K_{R}^{*}}{\partial c_{R}}>0$ follows the proof that $\frac{\partial K^{*}}{\partial c}>0$ in corollary 2 .

Proof of Proposition 3. Noting that with a symmetrical distribution the expected value of $X$ lies in the middle of the range of possible values of $X$ such that $\operatorname{Pr}[X>E(X)]=\operatorname{Pr}[X<E(X)]=\frac{1}{2}$, where $E(X)=\frac{L}{2}$ since $X \in[0, L]$.

1. This part is straight forward, if $K_{R}^{*}$ is chosen such that the equilibrium probability of regulatory breach $\Phi$ is equal to one-half, that is $\operatorname{Pr}\left[X>X_{R}^{*}\right]=\frac{1}{2}$, then it must be the case that $X_{R}^{*}=E(X)$ and expected precautionary regulatory capital is zero. 
2. If $K_{R}^{*}$ is chosen such that the equilibrium probability of regulatory breach $\Phi$ is less-than one-half, that is $\operatorname{Pr}\left[X>X_{R}^{*}\right]<\frac{1}{2}$, then it must be the case that $X_{R}^{*}>E(X)$ and expected precautionary regulatory capital is positive. As noted in the main text, the expected value of precautionary capital, if any, is given by the partial expectation of $X$ over the range of $X$ that would lead to expected precautionary capital, or:

$$
\int_{E(X)}^{X_{R}^{*}} X f(X) d X=\int_{\frac{L}{2}}^{X_{R}^{*}} X f(X) d X
$$

Integrating by parts and noting that $F\left(\frac{L}{2}\right)=\frac{1}{2}$ and $F\left(X_{R}^{*}\right)>\frac{1}{2}$ we get the desired result

$$
\begin{aligned}
\int_{\frac{L}{2}}^{X_{R}^{*}} X f(X) d X & =[X F(X)]_{\frac{L}{2}}^{X_{R}^{*}}-\int_{\frac{L}{2}}^{X_{R}^{*}} F(X) d X \\
& =X_{R}^{*} F\left(X_{R}^{*}\right)-\frac{L}{2} \frac{1}{2}-\int_{\frac{L}{2}}^{X_{R}^{*}} F(X) d X \\
& =X_{R}^{*} F\left(X_{R}^{*}\right)-\left[\frac{L}{4}+\int_{\frac{L}{2}}^{X_{R}^{*}} F(X) d X\right] \\
& >\frac{X_{R}^{*}}{2}-\left[\frac{L}{4}+\int_{\frac{L}{2}}^{X_{R}^{*}} F(X) d X\right] \\
& =X_{R}^{*}-\left[\frac{L}{2}+2 \int_{\frac{L}{2}}^{X_{R}^{*}} F(X) d X\right]
\end{aligned}
$$

3. If $K_{R}^{*}$ is chosen such that the equilibrium probability of regulatory breach $\Phi$ is greater than one-half, that is $\operatorname{Pr}\left[X>X_{R}^{*}\right]>\frac{1}{2}$, then it must be the case that $X_{R}^{*}<E(X)$ and expected precautionary regulatory capital is negative, alternatively, we can view this as an expected deficiency in regulatory capital for the bank. Recall the expected value of capital deficiency, if any, is the partial expectation of $X$ over the range of $X$ that would lead to an expected capital deficiency, or:

$$
\int_{X_{R}^{*}}^{E(X)} X f(X) d X=\int_{X_{R}^{*}}^{\frac{L}{2}} X f(X) d X=-\int_{\frac{L}{2}}^{X_{R}^{*}} X f(X) d X
$$

we can see that the expected value of capital deficiency is just the negative of the expected value of precautionary capital, leading to the desired result in the text.

Proof of Lemma 1. We want the equilibrium probability of regulatory breach to be less than one-half, that is:

$$
\frac{\rho-i}{c_{R}}\left(\frac{(1+r)(1-q)}{(1+i)}\right)<\frac{1}{2}
$$




\section{Capital Requirements in Banking}

Thus it must be the case that

$$
\begin{aligned}
\frac{1}{2} & >\frac{\rho-i}{c}\left(\frac{1+r}{1+i}\right) \frac{c}{c_{R}}(1-q) \\
& =\Psi \frac{c}{c_{R}}(1-q)
\end{aligned}
$$

Rearranging leads to the desired result.

\section{Proof of Lemma 2.}

1. Recall the condition for regulatory breach is $(\hat{X}-X)<q(L-X)$, rearranging, the condition becomes $X>\frac{\hat{X}-q L}{1-q} \equiv X_{R}$. From equation (7) in the text we know that $\hat{X}^{*} \equiv\left(\frac{1+i}{1+r}\right) K^{*}+\left(\frac{r-i}{1+r}\right) L$. Noting that $K \in[0, L]$ now consider:

$$
\begin{aligned}
X_{R}^{*}-\hat{X}^{*} & =\frac{\hat{X}^{*}-q L}{1-q}-\hat{X}^{*} \\
& =\frac{q}{1-q}\left(\hat{X}^{*}-L\right) \\
& =\frac{q}{1-q}\left(\left(\frac{1+i}{1+r}\right) K^{*}+\left(\frac{r-i}{1+r}\right) L-L\right) \\
& =\frac{q}{1-q}\left(\frac{1+i}{1+r}\right)\left(K^{*}-L\right) \\
& \leq 0
\end{aligned}
$$

Therefore, we have $\hat{X}^{*} \geq X_{R}^{*}$ and $\int_{X_{R}^{*}}^{L} f(X) d X=\operatorname{Pr}\left[X>X_{R}^{*}\right] \geq \int_{\hat{X}^{*}}^{L} f(X) d X=$ $\operatorname{Pr}\left[X>\hat{X}^{*}\right]$.

2. Consider the equilibrium probability of regulatory breach

$$
\begin{aligned}
\Phi & =\frac{\rho-i}{c_{R}}\left(\frac{(1+r)(1-q)}{(1+i)}\right) \\
& =\frac{\rho-i}{c}\left(\frac{1+r}{1+i}\right) \frac{c}{c_{R}}(1-q) \\
& =\Psi \frac{c}{c_{R}}(1-q)
\end{aligned}
$$

where $\Psi=\frac{\rho-i}{c}\left(\frac{1+r}{1+i}\right)$ is the equilibrium probability of bankruptcy. Since part 1 tells us that $\Phi \geq \psi$, from (A18) this can only be the case if

$$
\frac{c}{c_{R}}(1-q) \geq 1
$$

Or

$$
c_{R} \leq c(1-q)
$$




\section{International Review of Finance}

Proof of Proposition 4. Lemma 2 gives us an upper limit for the per dollar cost of breach $c_{R} \leq c(1-q)$. Lemma 1 gives us a lower limit for the per dollar cost of breach $c_{R}>2 \Psi c(1-q)$ below which banks are expected to have a regulatory capital deficiency. It follows that both conditions can only be satisfied if $2 \Psi<1$, or alternatively $\Psi<\frac{1}{2}$. That is, the equilibrium probability of bank failure is less than half and banks are therefore expected to survive. 